Song Yicai

\title{
THE DEVELOPMENT OF 20 CENTURY REALISTIC OIL PAINTING IN CHINA
}

Stroganov Moscow State University of Arts and Industry

9, Volokolamskoye sh., Moscow, 125080, Russian Federation.

This article analyses a new period in the methods of teaching the fine arts in China at the Central Academy of Fine Arts which, in the mid-twentieth century, began to intensify. Numerous representatives of artistic figures during this period came to China from the Soviet Union and the socialist countries of Eastern Europe. Soviet masters were invited to China to establish courses, creating conditions for the systematic development of realistic painting techniques. Particular attention is paid here to the Soviet artist K. Maksimov's educational activities. With a particularly logical and effective method of teaching oil painting, he made a significant contribution to the development of Chinese artists' systemic approach to realism. The consistent process of realism's influence in Chinese art is also considered in the context of the educational activities of such significant artists of this school as Xu Beihong, Wu Zuoren and others. Analysis of K. M. Maksimov's students' works presented at the exhibition of graduates of his course, allows one to conclude that a the artist's pedagogical activities had a special historical significance for China. The author of the article concludes that it was only the hard work and diligence of Maksimov's students which enabled a quick response of the Academy of Arts to the necessity of educating a new type of Chinese artist which was, from beginning of the 1980s, to dictate reform and a policy of openness. Refs 5 . Figs 9.

Keywords: Xu Beihong, K. M. Maksimov, China, oil painting, realism, visual arts education, educational institutions, Academy of Fine Arts.

\section{РАЗВИТИЕ РЕАЛИСТИЧЕСКОЙ ЖИВОПИСИ В КИТАЕ В СЕРЕДИНЕ ХХ ВЕКА}

\author{
Сун ИЦай
}

Московская государственная художественно-промышленная академия им. С. Г. Строганова, Российская Федерация, 125080, Москва, Волоколамское ш., 9

В статье анализируется новый период в методике преподавания изобразительного искусства в Китае в Центральной Академии изящных искусств, который активизировался в середине XX века. В этот период в Китай прибывают многочисленные представители художественных деятелей из Советского Союза и социалистических стран Восточной Европы. Приглашенные в Китай советские мастера учреждают курсы, создавая все условия для системного освоения реалистического метода в живописи. Особое внимание уделяется педагогической деятельности советского художника К.М.Максимова, обладавшего логичным и эффективным методом обучения масляной живописи, внесшего весомый вклад в системное освоение китайскими художниками подхода к созданию реалистических художественных произведений. Последовательный процесс проникновения реализма в китайскую живопись рассматривается также в контексте педагогической деятельности таких значительных художников этого направления, как Сюй Бэйхун, У Цзожэнь и др. Анализ работ учеников К.М.Максимова, представленных на выставке выпускников его курса, позволяет сделать вывод об особой исторической значимости педагогической деятельности этого художника в Китае. Автор статьи резюмирует, что именно благодаря трудолюбию и стараниям учеников Максимова с началом 80-х годов 20 века оказалась возможной столь быстрая реакция Академии искусств на продиктованную политикой реформ и открытости необходимость воспитания нового типа творческих деятелей Китая. Библиогр. 5 назв. Ил. 9.

Ключевые слова: Сюй Бэйхун, К. М. Максимов, Китай, масляная живопись, реализм, художественное образование, учебные заведения, Академия изящных искусств.

In the beginning of the 1950s, active cooperation in the field of culture and art expanded between the Peoples Republic of China (PRC) and the USSR within the limits of which a huge number of students from the PRC were sent to study in the Soviet Union

(C) Санкт-Петербургский государственный университет, 2016 
and Eastern Europe. At the same time many artistic figures came to China from the Soviet Union and the socialist countries of Eastern Europe. Soviet masters were invited to China to establish courses where they taught students from all over the country, creating the conditions for a systemic penetration of Soviet artistic traditions into China. Among the invited eachers was the artist K. M. Maksimov ${ }^{1}$, who arrived in China after being dispatched by the government on 19 February 1955.

The purpose of education in the Central Academy of Fine Arts at the time was the preparation of the artistic personages were to realise governmental propaganda and agitprop objectives in society. There were no other higher-level requirements. The curriculum of the "courses of oil painting" offered by K. M. Maksimov, had to be completed within a very short, two year term. Therefore, its curriculum was quite different from the one of the Central Academy of Fine Arts which was aimed at training advanced artists to receive the education needed for masters of fine arts.

On the first year of education, in 1955, K. M. Maksimov was at the head of the basic oil technique classes. Beginning from 1956, he began to accentuate the development of graduate work. In general, K. M. Maksimov's oil painting programmes were assembled from a brief acquaintance with a particular theoretical basis and more detailed practical courses. As a whole, the educational program included a transition from a live model to gypsum figures, from drawing to oil painting, from studying in studios to the open air, from the sketch of the composition to the creation of the finished product.

Before the work of the invited Soviet educators, who successfully began to develop a training program under K. M. Maksimov's guidance, the Central Academy of Fine Arts developed and put into practice its own teaching methods. Almost every teacher at that time was a major artist. Among them were Jiang Chzhaohe, Li Keran, E Tsyanyuy and others. In the field of painting particularly outstanding was Li Keran, who taught different techniques of painting.

Meanwhile, a student from Maksimov's courses Chen Basin said that the subjects taught in the programs of the Central Academy of Fine Arts had been isolated and not connected, leading to the sense that the programmes lacked a theoretical coherence. The method of education of the Central Academy of Fine Arts consisted in the fact that every teacher conducted his own educational bloc. In contrast to the system of education customary in Chinese academies, K. M. Maksimov's involved all disciplines: drawing, oil painting, composition, outdoor painting.

K. M. Maksimov believed that learners must be trained into artists - in his curriculum each part of the course interrelated with the other, including a wealth of educational material.

The art and pedagogical merits of representatives of the old generation of artists such as Xu Beihong ${ }^{2}$, Wu Zuoren ${ }^{3}$ et al., were widely accepted before the liberation of China.

${ }^{1}$ Constantine Mefodevich Maksimov (1913-1994) - Soviet painter and teacher. People's Artist of the RSFSR. The winner of two Stalin Prizes (1950, 1952), was trained in G. G. Ryazhsky workshop at the Moscow Art Institute, after graduation he taught at the Faculty of oil painting at the Moscow State Academic Art Institute named after Surikov.

2 Xu Beihong (19 July 1895 - 26 September 1953), the Chinese painter and graphic artist, one of the first Chinese artists of the 20th century brought together national artistic traditions with the achievements of European painting. (https://ru.wikipedia.org/ date of access: 20.12.2015)

3 We Zuoren (1908-1997), studied in Belgium from 1930-1935, returning to China taught at the Central Academy of Fine Arts, later becoming rector. 
However, comparing their pedagogical approach with the approach of the masters of oil painting from Maximov's group, students unanimously recognised the advantages of the Soviet-Russian school, consisting in a logical sequence and effectiveness of educational techniques.

K. M. Maksimov began to promote the new creative method characterised by a special focus on light and shadow modelling and variability of colours depending on the light [1, p. 47]. These basics of oil painting were reflected in $\mathrm{Xu}$ Beihong's educational methodology, which established the Faculty of Education in the Central Academy of Fine Arts. He took the "baton" from the Russian school of oil painting education and began to implement its method of displaying outoor light.

The distinguishing features of Maksimov's educational point of view consisted in the interconnectedness of progressive stages of training and the overall integrity of the teaching process, the ability to substantially influence on the development of students' powers of observation and ability to express themselves.

Among K.M.Maksimov's students was a large number of artists, who have graduated from the Central Academy of Fine Arts under the guidance of Xu Beihong. Among them - Feng Fasy, Jin Shan, Yu Yunjie, Hou Yiming. In his memoirs, Feng Fasy writes: ".... My base was formed in the 1930s, it is necessary to thank Xu Beihong, Yan Venlyan, Pan Yuylyan, Wu Zsuoren and other senior luminaries of oil painting. Studying in the courses we acquired a very big practical experience, which related mainly to the display of colour. In addition, I also acquired the basic laws of colour from older generations of artists of oil painting, but I believe that K. Maximov's teaching method is more scientific" [2, p. 19-20].

Under Maksimov's guidance the students perceived the subtleties of working indoors and outdoors, on cloudy and clear days, the secrets of the image of lit and dark sides and so on. Jin Shani recalls: “There is something different - the balance of figures' positions under sunlight, it can be said, that it originates from it. Despite the fact that I started very early to study oil painting, earlier we mainly painted landscapes in the open air, there was no location of people outdoors in the sun until this time" [3, p. 26].

The first group of Chinese students came to study art in the Soviet Union in 1953. Only six years later, in 1959, did they receive their diplomas and return to their homeland, whereas K. M. Maksimov's courses were started in 1955. Jin Shani believed that the biggest achievement of "K. M. Maksimov's Oil Painting Courses" was to bring three subjects into Chinese art education: drawing, painting and composition. This method of education and such theoretical ideas allowed students to comprehensively and systematically master the method of painting on canvas in the style of realism at a high artistic level. Jin Shan said about those who studied directly in China: “... how to create the structure of a composition, story, how to portray people in reality — this knowledge had its foundations only here. How to create a composition in the creative process, what the basic principlesnare, all of it became clear at once" [3, p. 27].

One of K. M. Maksimov's students Zhan Jianjun said: "What is the process of oil painting? I only received the answer to this question at Maksimov's lessons. It turned out that all processes beginning with the accumulation of life experience to gathering the necessary information - from creation of a sketch to completion of the work - have their own texture and must meet certain requirements. Exactly this technique has formed the basis of my own creative and educational points of view. The scientific nature and effectiveness 
of this technique have been proven many times in practice" [4]. This is a logical conclusion of a very special nature of the contribution made by the Soviet school of artists in the formation of new Chinese painting traditions.

On 24 May 1957, in the auditorium of the Central Academy of Fine Arts, an exhibition of K.M.Maksimov's oil painting students' diploma works was inaugurated. The exhibition, which contained more than 100 paintings, aroused great interest; it was even visited by a prominent military man, statesman and politician, one of the closest of Mao Zedong's associates, Marshal Zhu De.

The exhibition evoked a great response in the artistic community because, before that time, China had not had similar exhibitions where such a large number of realistic works, executed in the technique of oil painting were represented in one place. Also, until that time very few multi-figure genre canvases had been created in China. Only shortly before a small number of paintings created on the theme of the history of the revolution, such as the "Ceremony of the PRC Proclamation" by Dong Xiwen, "Underground Battle" by Lo Gunlyu etc had been exhibited. For the first time since the founding of New China, the exhibition presented paintings in such large number. Plots for the pictures reflecting real life of the society, were drawn by artists from the everyday life of their contemporaries. Among such works were: "Creating the Family Hearth" by Zhan Jianjun (Fig. 1), "Rich Harvest Season" by Ren Menchzhana (Fig. 2), as well as one of the most important events in the history of the revolution - "Liu Hulan Stands on the Side of Justice" by Feng Fasy (Fig. 3), "Sisters of a Hero" by Van Davao (Fig. 4). Along with genre works were exhibited portraits and landscapes: "Lunch" by Wei Chuan (Fig. 5), "Dawn on the Yangtze River" by Yuan Hao (Fig. 6).

This event was unprecedented in the history of Chinese art in scale and response from all segments of society. The Shanghai publishing house of folk art released "Album of Works in Oil Painting"4, in which were collected all the exhibited artists' works.

The knowledge learned during education in Maksimov's group, complemented by Chinese artists' individual creative and pedagogical experience was subsequently handed over to their students. It shows us the historical continuity of the educational tradition. Here is an example of a landscape by Chen Basin (Fig. 7). The artist's unusually sensitive attention to the interconnection of colour elements and touches in the image makes his creative point of view unique phenomenon of Chinese oil painting. Xin Shangyi paid special attention to the concept proposed by Maksimov of artistic compositional structure (Fig. 8), Feng Fasy (Fig. 3) and Chen Basin (Fig. 7) focused on the art of colour, Shang Hushen (Fig. 9) was most concerned by the issue raised by Maksimov on the "nature of painting", Hou Yimin (Fig. 10) managed to have a sense of mastery in the spirit of dialectic permeating Maksimov's pedagogical principles, Wei Chuan (Fig. 5) gives priority to gradualness and systematic character, inherent to the educational methodology of the Soviet master. The significance of Maksimov's lessons for Ren Menchzhan (Fig. 2) was not so much in the possibility of improving the creative technique as in the ability to update creative thinking, awareness of the importance of colour in the process of the expression of artistic conception.

Subsequently, most graduates of Maksimov's courses, except Gao Hu, who took the post of head of the creative department of the National War Museum and Ho Kunde,

4 Editorship of the Central Academy of Fine Arts, Folk Art publishing house of Shanghai, the publication in March 1959. Edition of 2,000 copies. 


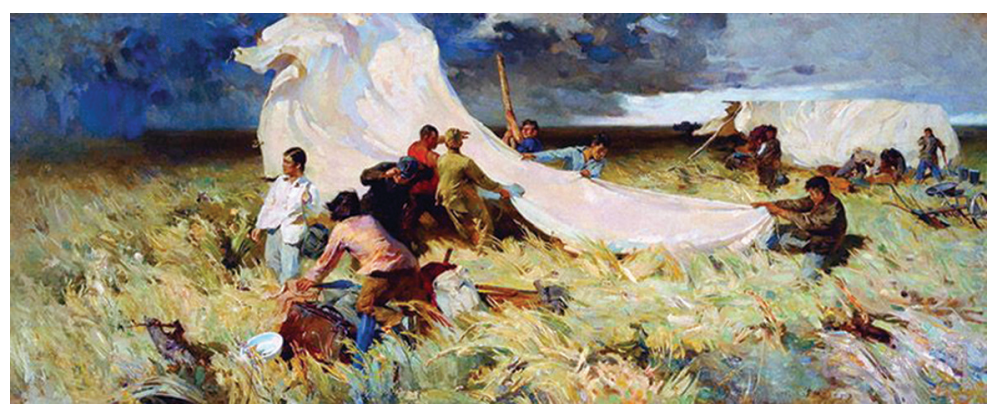

Fig. 1. Zhan Jianjun. Creation of a family hearth. 1957

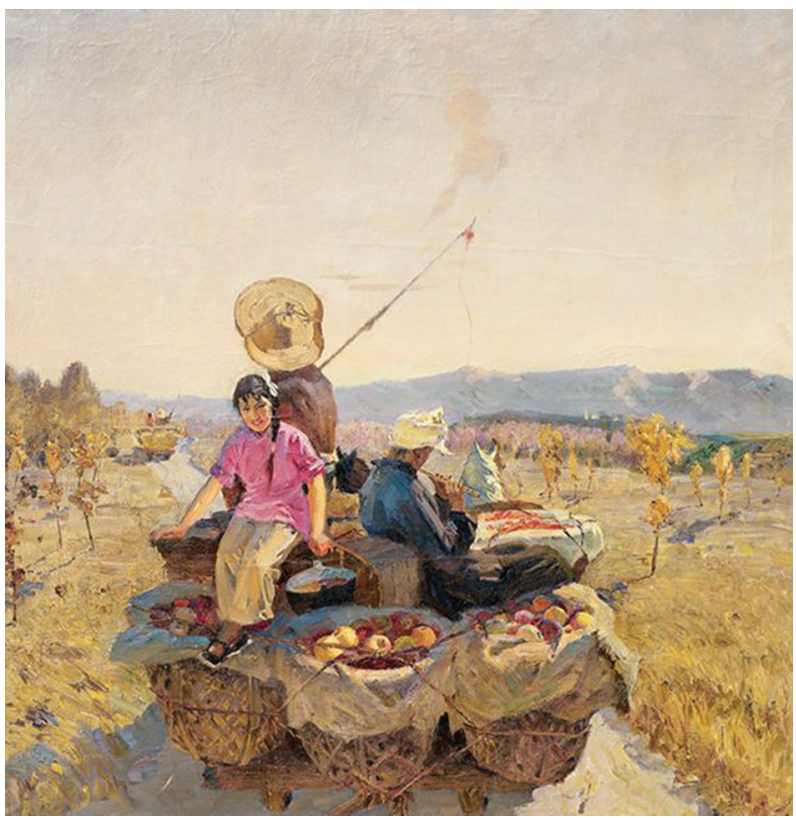

Fig. 2. Ren Mengzhang. Season of rich crop. 1957

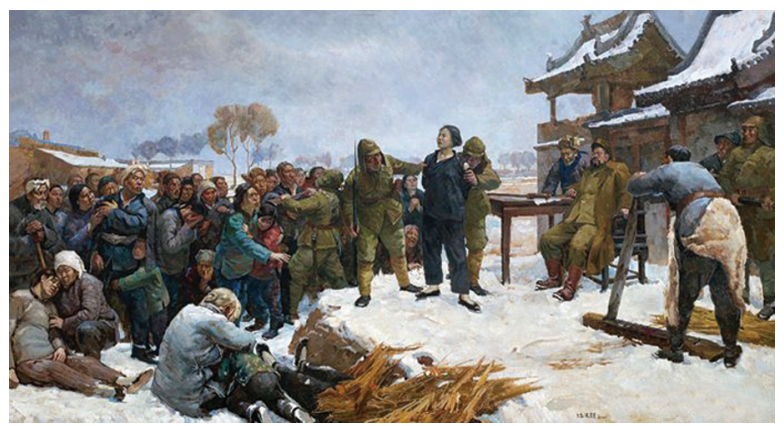

Fig. 3. Feng Fasi. Liu Hulan stands on the side of justice. 1957 


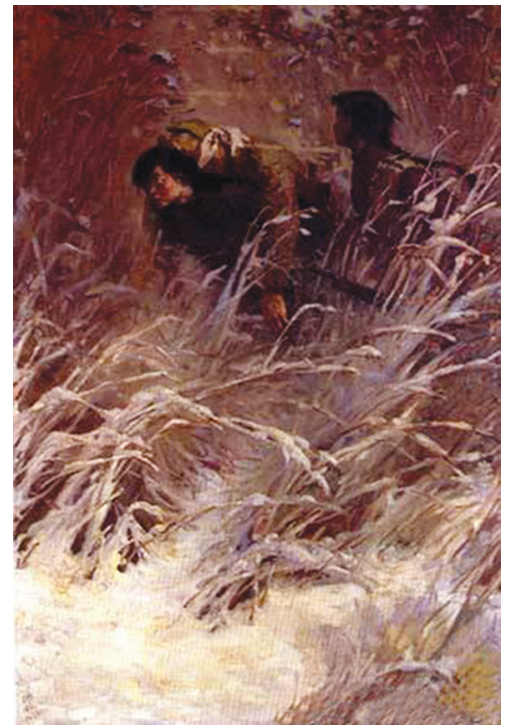

Fig. 4. Wan Dewei. Hero's

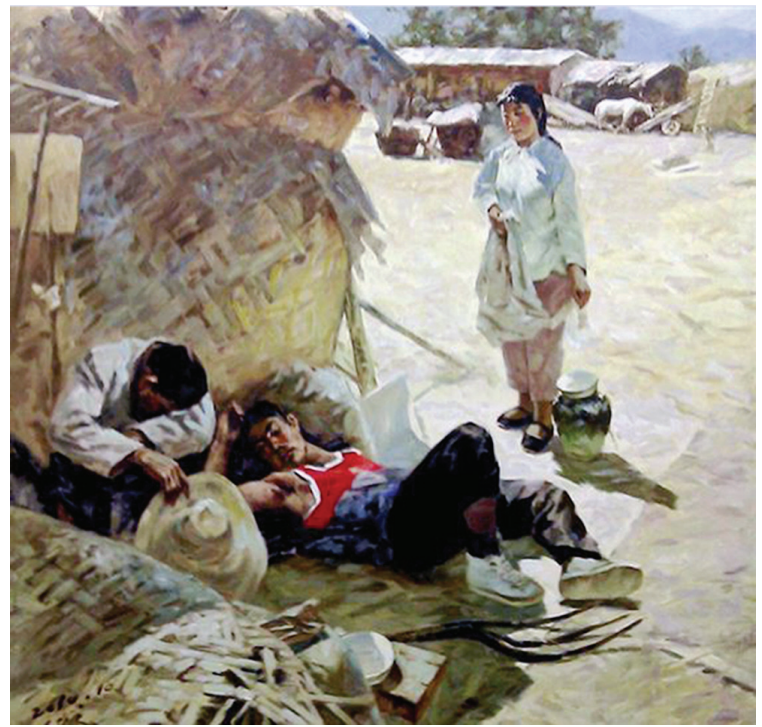

Fig. 5. Wei Chuanyi. Break before lunch. 1957 sisters. 1957

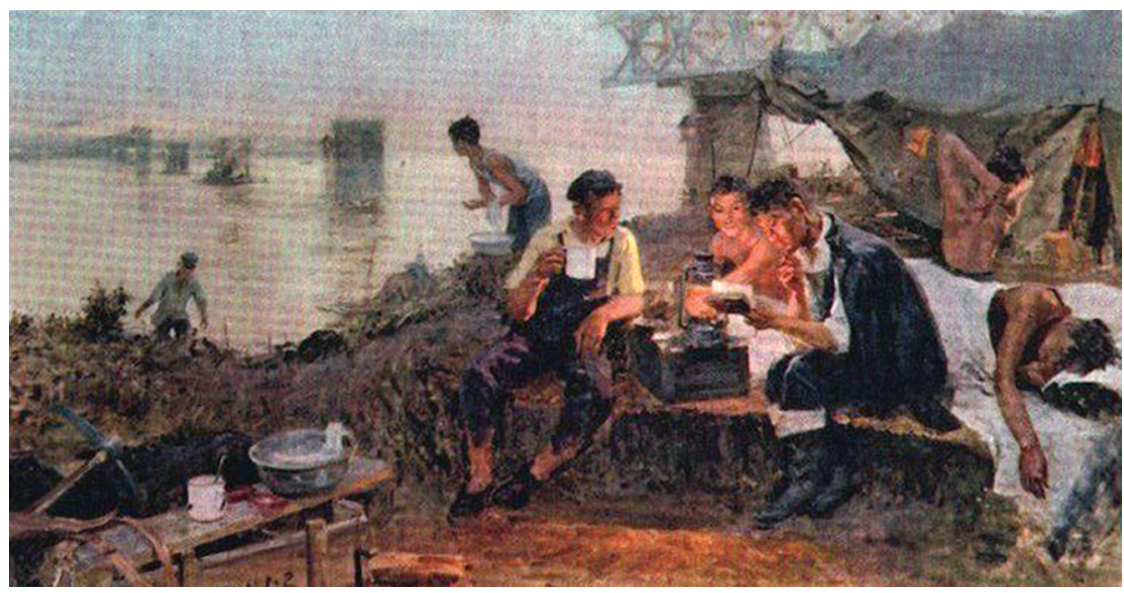

Fig. 6. Yuan Hao. Dawn on the Yangtze River. 1957

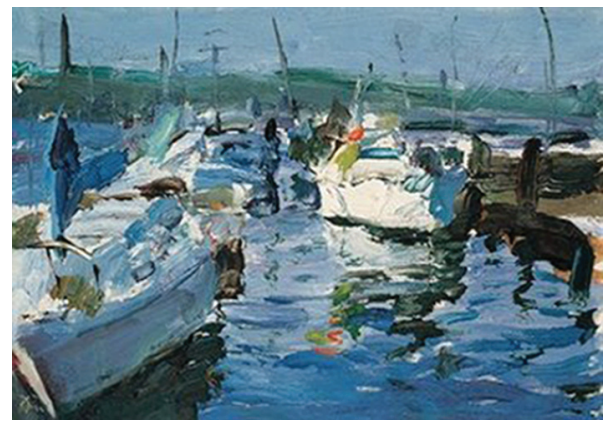

Fig. 7. Zhan Baixin. Harbour. 1992 


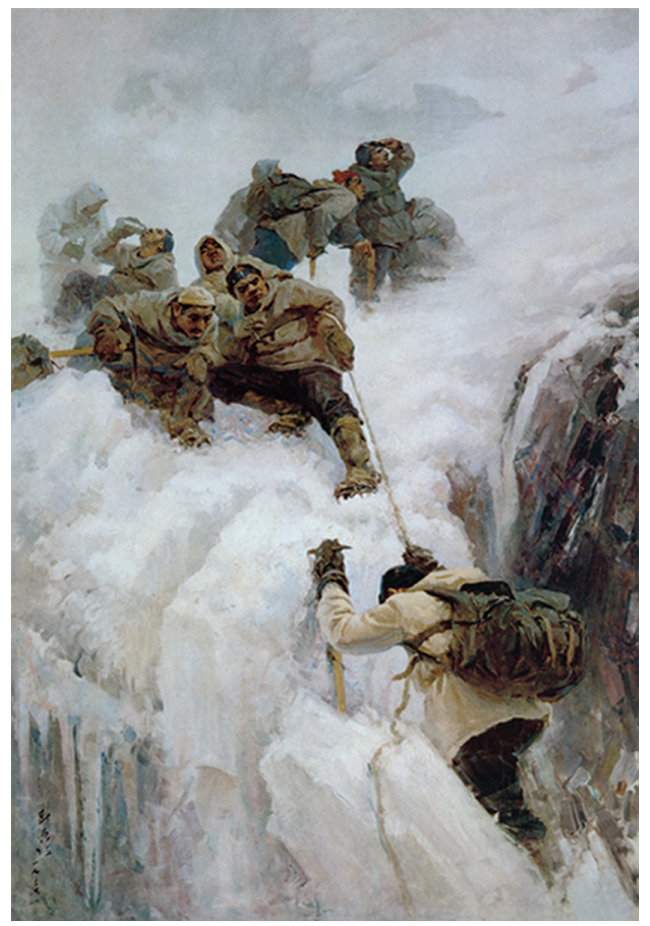

Fig. 8. Jin Shangyi. Climbing the snow mountain. 1957

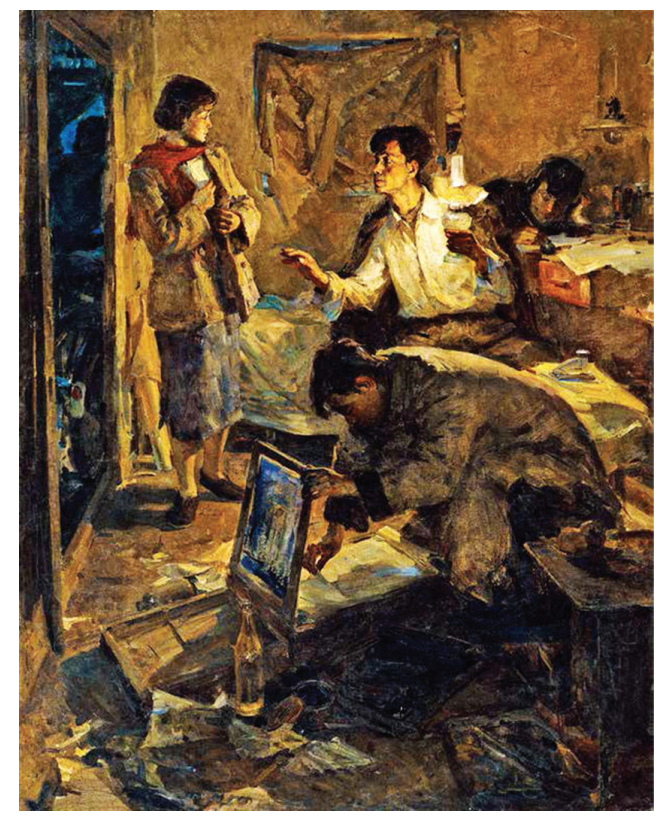

Fig. 9. Hou Yimin. Intelligence of the Revolution. 1957

who devoted himself directly to creative activity, engaged in educational work at various art institutes of the country, thus becoming the support of artistic and scientific circles, engaged in the development of oil painting.

Undoubtedly, the Soviet system of the creative method of realism presented in the context of "K. M. Maksimov's Oil Painting Course" had an impact on Chinese national art schools. The pedagogical approach of course graduates, which devoted themselves to educational activities, was based on Maksimov's educational methodology and complemented with their own experience and individual scientific research. Precisely because of the hard work and diligence of Maksimov's students, the Academy of Arts was able to make a quick response to the need to educate a new type of creative figure dictated by reform and the policy of openness at the beginning of the 1980s.

Assessing the achievements of Maksimov's group, a professor of the Central Academy of Fine Arts of China Ai Zhongxin5, in his article "Memories of Chinese oil painting of 50's and early 60's" wrote: "K. M. Maksimov's merits are obvious and they come out not only in high quality of the students' final works, but also in the obvious changes that characterise the level of professionalism of the masters of oil painting, including graduates of art academies across China in the mid and late 50s. In the 60s these achievements become even brighter. Through the Houses and Palaces of culture oil painting deeply penetrated

${ }^{5}$ E Zhongxin (October 15. 1915 - 28 December. 20013) Xu Beihong's and Wu Tszuozhen's student, professor at the Central Academy of Fine Arts. 
into the masses, gained adherents in all large and medium cities of the country. It must be assumed, that many of them became the successors of professional oil painters later. Society is a kind of university where experienced masters lead the younger generation of artists, and the distribution of oil painting takes place at a lower level" [5, p. 7].

\section{References}

1. My way in the oil painting - Jin Shani memories. Moscow, Tszilian Fine Arts publishing, 2000. 47 p.

2. The views on Arts. 2004. Edition 5, pp. 19-20.

3. The introduction and development of oil painting in China - record of a dialogue with Jin Shani. Fine Arts Studies, Edition 2. 27 p.

4. "K. M. Maksimov's oil painting courses" and Chinese oil painting. Available at: http://www.xzbu.com/5/ view-3754197.htm (accessed 15.11.2015).

5. Fine Arts. 11. 1989. Article 7.

For citation: Song Yicai. The development of $20^{\text {th }}$ century realistic oil painting in China. Vestnik of SaintPetersburg University. Ser. 15. Arts, 2016, issue 2, pp. 36-43. DOI: 10.21638/11701/spbu15.2016.203

Для цитирования: Сун И Цай. Развитие реалистической живописи в Китае в середине XX века // Вестн. С.-Петерб. ун-та. Сер. 15. Искусствоведение. Вып. 2. С. 35-43. DOI: 10.21638/11701/ spbu15.2016.203

Статья поступила в редакцию 24 февраля 2014 г.

Контактная информация :

Сун И Цай - аспирант: уiсаi99@163.rcom

Song Yicai — graduate student: yicai99@163.rcom 